\title{
PENERAPAN MODEL RAPID APPLICATION DEVELOPMENT MENGUNAKAN SOCIAL MEDIA CONTENT MARKETING BAGI UMKM DALAM MENGHADAPI PERSAINGAN MASYARAKAT EKONOMI ASEAN (MEA)
}

\author{
Esti Wijayanti, Evanita \\ Teknik Informatika, Fakultas Teknik, Universitas Muria Kudus \\ esti.wijayanti@umk.ac.id, evanita@umk.ac.id
}

\begin{abstract}
Marketing is important for the entrepreneur who produces the good produced. In this global competition, entrepreneurs have to find solutions to face the market how to market the production goods in order to be sold and received to the outside community. One solution to disseminate information is by sticking advertisement whose contents concern the quality of production goods, information from neighbors and benner. The current title is advertisement in society is by utilizing internet technology, that is through the website (website) that can be accessed around the world. This website can be used as marketing promotion tool of umkm production in Kudus. Before building the website is required analysis and design so that the resulting system can be as much as possible. With the modeling of Unified Modeling Language and php programming language and mysql database, and social media content marketing (SMCM) is a research approach to explore variations in the marketing experience of the community about using information, the development of information based information systems can provide information generated website that can be used as media information to find out the umkm goods product in Kudus.
\end{abstract}

Keywords: social, media, content, marketing, unified

\begin{abstract}
Abstrak
Pemasaran sangat penting bagi pengusaha yang memprduksi barang yang dihasilkan. Pada persaingan global ini pengusaha harus mencari solusi untuk menghadapi pasar bagaimana cara untuk memasarkan barang produksi agar laku dan diterima pada masyarakat luar. Salah satu solusi untuk menyebarkan informasi dengan cara menempelkan brosur yang isinya mengenai kualitas barang produksi, informasi dari tetangga dan benner. Pemarasan yang sekarang ini sedang mengema di masyarakat adalah dengan cara memanfaatkan teknologi internet, yaitu melalui situs internet (website) yang dapat diakses di seluruh dunia. Website ini dapat digunakan sebagai sarana promosi pemasaran produksi umkm di Kudus. Sebelum membangun website tersebut diperlukan analisa dan perancangan agar sistem yang dihasilkan dapat semaksimal mungkin. Dengan pemodelan Unified Modelling Language dan bahasa pemrograman php serta database mysql, dan social media content marketing (SMCM) merupakan pendekatan penelitian untuk mengeksplorasi variasi dalam pengalaman pemasaran masyarakat tentang menggunakan informasi, pengembangan sistem informasi berbasis website mampu memberi informasi dihasilkan website yang dapat digunakan sebagai media informasi untuk mengetahui produk barang umkm di Kudus.
\end{abstract}

Kata kunci: social, media, content, marketing, unified

\section{PENDAHULUAN}

Para penguasaha kecil atau yang disebut usaha kecil dan menengah (UMKM) di kota kudus biasanya memasarkan barang produksinya di pasar local sehingga produk hanya disajiakan pada masyarakat sekitar, kota Kudus adalah salah satu kota yang terletak di sebelah utara pulau jawa kota kecil ini, salah satu hal yang wajar apabila para pengusaha membutuhkan pemasaran yang tepat agar seluruh masyarakat mengetahui informasi produk yang ada pada kota kudus.

Tahu adalah bahan makanan dengan bahan dasar kacang kedelai lokal maupun impor yang biasa dikonsumsi oleh masyarakat Indonesia. Tahu yang mengandung energi, protein, karbohidrat, lemak, kalsium, fosfor, dan zat 
besi. Selain itu di dalam. Tahu juga terkandung vitamin $\mathrm{A}$, vitamin $\mathrm{B} 1$ dan vitamin $\mathrm{C}$.

Analisis situasi pasar produksi tahu yang biasanya kita sebut market share adalah pasar yang selama ini ada biasanya dikuasai oleh perusahaan besar. Sehingga para penguasa kecil atau yang disebut usaha kecil dan menengah (UMKM) mengalamai kesulitan dalam pemasaran yang tradisional terhadap keseluruhan penjualan seluruh pesaing.

Gambaran produksi pada usaha tahu dapat di lihat pada Gambar 1. Pembuatan tahu yang masih terbilang sangat konvensional dan juga penjualannya yang masih mengunakan metode bertemuanya calon pembeli dan penjual pada tembat yang sama untuk bertransakasi.

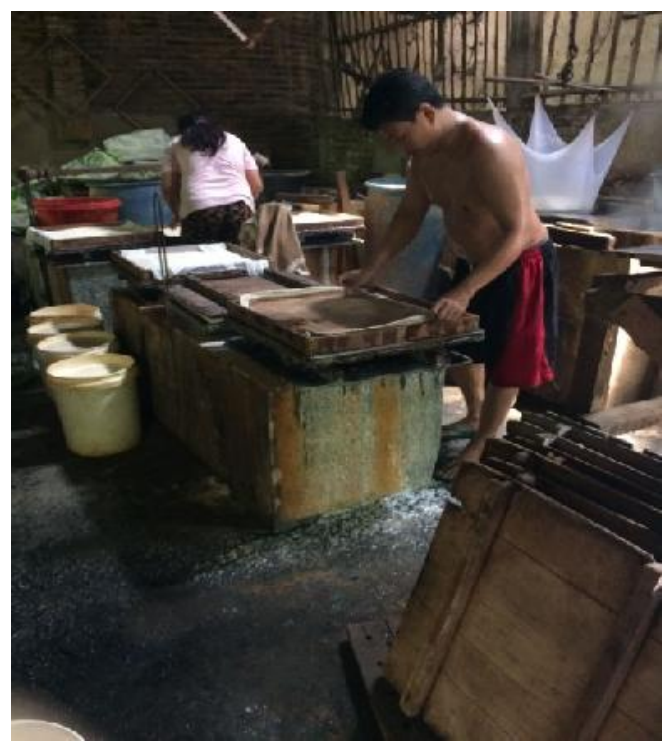

Gambar 1. Produksi Pembuatan Tahu

Transakasi melalui internet telah menjadi trend di era tahun 2018 ini dan makna pasar yang sebenarnya telah dikemas sedemikian praktisnya sehingga user pun merasa dimanjakan oleh fasilitas yang ada. Keberadaan internet tidak membatasi seseorang untuk melakukan transaksi, di mana saja dan kapan saja transaksi dapat terjadi. Hal ini mengambarkan apa terjadinya sebenarnya dapat mengambil gambar atau capture dapat dilihat oleh orang lain tanpa datang langsung ke lokasi. Dengan cara konvensional sangat menyulitkan para user mengetahui informasi yang diinginkan, dengan adanya teknologi ini user sangat terbantu dan berpengaruh terhadap peningkatan persaingan.
Sosial Media Content Marketing (SMCM) memainkan peran penting dalam kesehatan merek, karena merupakan media untuk konsumen untuk mendapatkan informasi tentang merek (Ahmad N.S., dkk., 2015).

Dengan mengunakan metode Sosial Media Content Marketing untuk mendesign web yang akan dirancang mengunakan Unified Modelling Language maka akan menghasilkan web untuk memudahkan pengusaha untuk memasarkan produk barang umkm yang ditawarkan dan user atau customer dapat mengetahui informasi produksi melalui web yang akan diimpelemtasikan.

\section{TINJAUAN PUSTAKA}

Sosial Media Content Marketing (SMCM) memainkan peran penting dalam kesehatan merek karena merupakan media untuk konsumen untuk mendapatkan informasi tentang merek (Ahmad N.S., 2015) Pada saat ini, para pengusaha cenderung menggunakan media pemasaran sosial untuk memasarkan tentang produk mereka kepada konsumen. Melalui social platform media, mereka terlibat dengan konsumen mereka dan membangun interaksi aktif antara mereka. Oleh karena itu, sangat penting untuk perusahaan untuk memiliki konten pemasaran yang baik untuk menarik lebih banyak pelanggan untuk mengunjungi halaman mereka. Berikut ini adalah framework penelitian social media content marketing untuk UMKM dalam menghadapi persaingan masyarakat ekonomi asean (MEA), yang ditunjukan pada Gambar 2: Gambaran kerangka sistem informasi yang di gunakan untuk mengimplemntasikan perangkat lunak ini sebagai berikut, yang dapat dilihat pada Gambar 2.

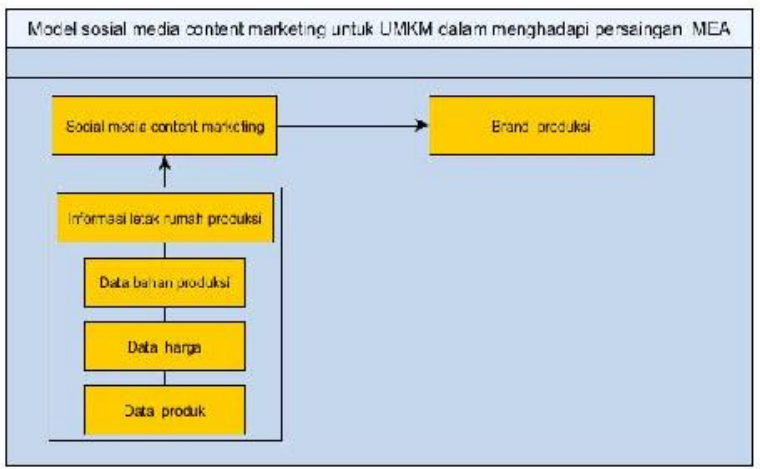

Gambar 2: Framework social media content marketing 
Adapun gambaran kerangka sistem informasi penelitian social media content marketing untuk UMKM dalam menghadapi persaingan Masyarakat Ekonomi Asean (MEA), untuk meningkatkan pendapatan pada UMKM dan pemasaran secara global yang akan diusulkan ditunjukan pada Gambar 3.

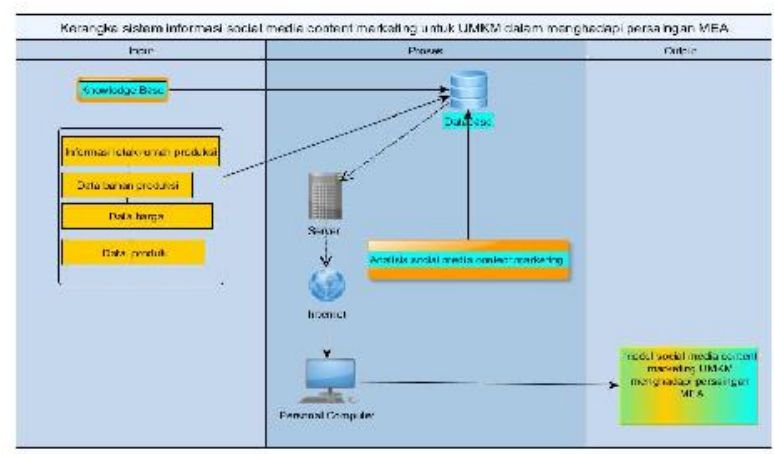

Gambar 3: Kerangka sistem penelitian Social Media Content Marketing bagi UMKM dalam menghadapi persaingan Masyarakat Ekonomi Asean (MEA)

\section{METODOLOGI}

Adapun metode pengembangan sistem yaitu RAD (Rapid Application Development)untuk dilaksanakan dalam kegiatan ini yang dapat dilihat pada Gambar 4, metode ini mampu memperbaiki sistem karena berkerja pada dalam workshop desain RAD mampu mengembalikan user untuk merancang sistem kemudian membangun sistem sesuai keinginan user lalu mebuat sistem baru dilihat pada Gambar 4.

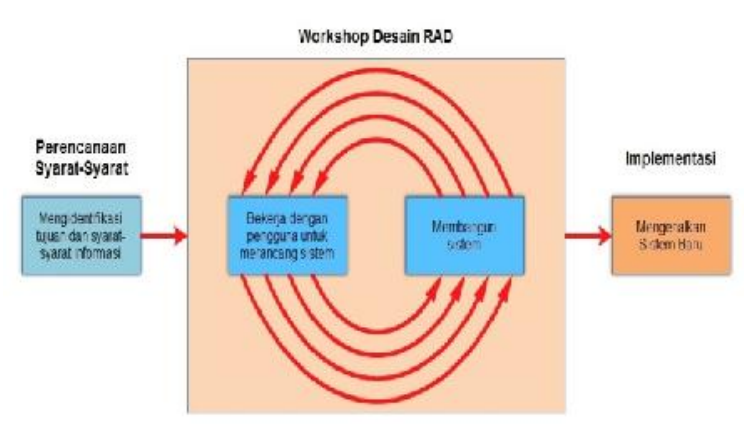

Gambar 4: Model Rapid Application Development
Tahapan model rapid application development untuk impementasi social media content marketing bagi umkm dalam menghadapi persaingan Masyarakat Ekonomi Asean:

1. Mengidentifikasi tujuan informasi.

Pada tahapan pertama adalah memahami informasi apa saja yang akan diberikan kepada user, user merupakan para pembeli yang akan membeli barang dari produsen dari seluruh manusia dengan mengunakan koneksi internet.

2. Bekerja dengan penguna untuk merancang sistem.

Pada sisi penguna menginginkan sebuah sistem yang user friendly untuk membuat user nyaman dalam transaksi dan melakukan trnsaksi berulang-ulang.

3. Membangun sistem.

Sistem yang akan dibangun berbasis web untuk kemudahan user bertransaksi dengan mengunakan perancangan UML (Unified Modelling Language) Untuk mengimplementasikan sistem baru.

4. Mengunakan sistem baru.

Sistem baru yang digunakan oleh user untuk bertransaksi jual beli.

\section{HASIL DAN PEMBAHASAN}

Pada tahapan perancangan sistem yaitu mengunakan UML (Unified Modelling Language) berikut ini adalah bisnis usecase diagram yang dapat dilihat pada Gambar 5 .

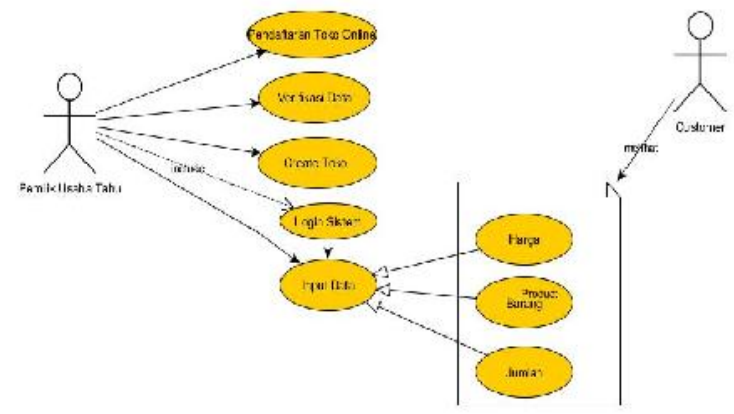

Gambar 5. Bisnis usecase diagram toko online

Pada Gambar 6 adalah pendaftaran toko online yaitu pendaftaran pemilik toko untuk menginformasikan barang yang akan di jual. 


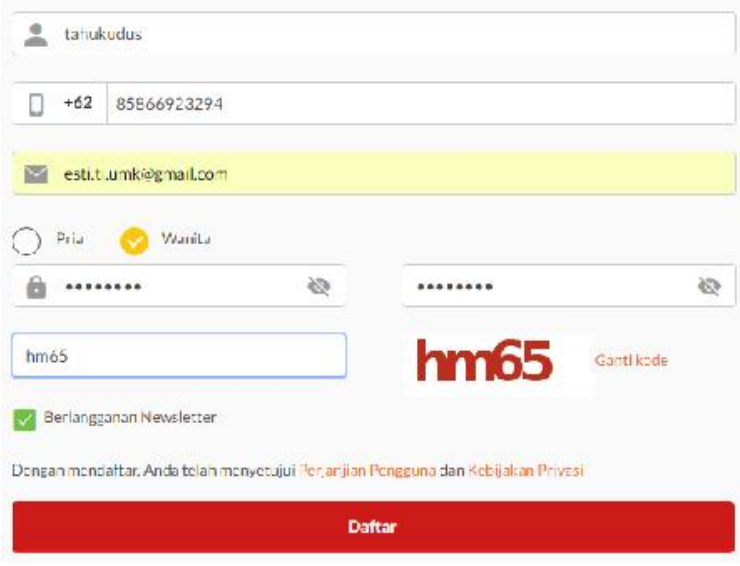

Gambar 6. Pendaftaran toko online

Sebelum mengakses web ke website toko online user dapat masuk ke form login. Form login dapat di lihat pada Gambar 7.

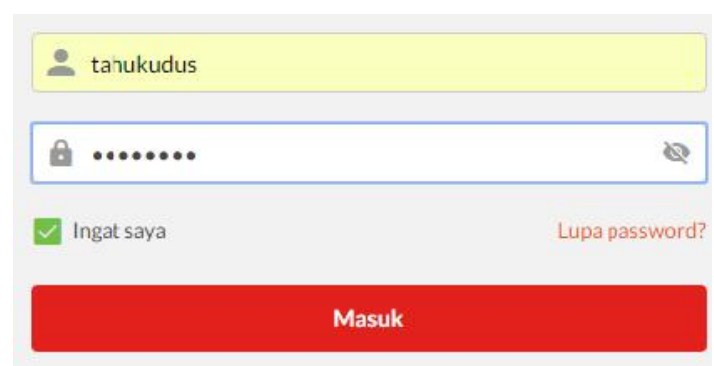

Gambar 7. Form Login untuk masuk ke website

Setelah masuk halaman website toko, pemilik usaha dapat membuka toko untuk memasarkan produk. Tampilan untuk membuka toko dapat di lihat pada Gambar 8.

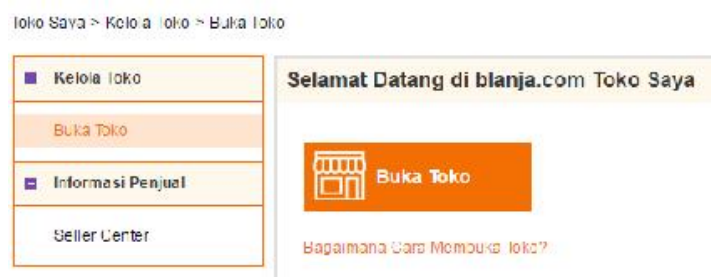

Gambar 8. Halaman buka toko

Mengisi nomor $\mathrm{Hp}$ untuk verifikasi pembuatan toko dapat dilihat pada Gambar 9

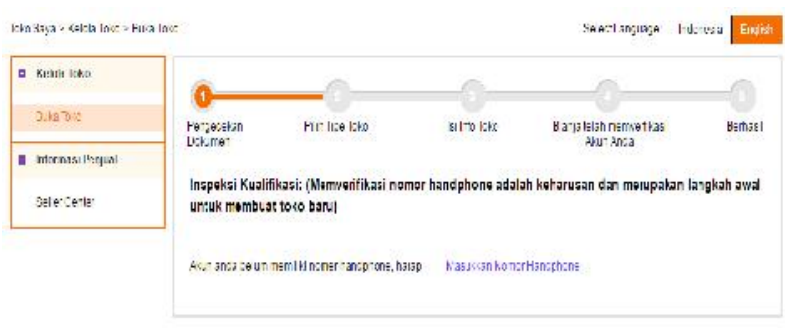

Gambar 9. Verifikasi nomor HP

Verifikasi nomor Handphone berhasil dapat dilihat pada Gambar 10.

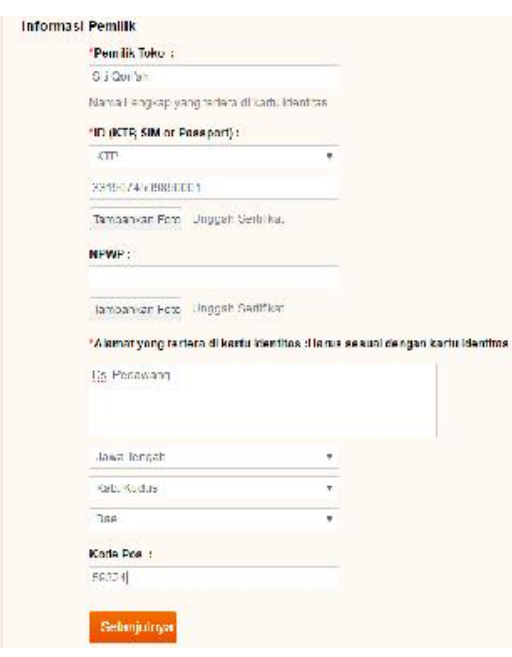

Gambar 10. Tampilan menu verifikasi nomor handphone

Langkah berikutnya adalah memberikan informasi secara detail untuk membuka toko online yang dpat dilihat pada Gambar 11 .

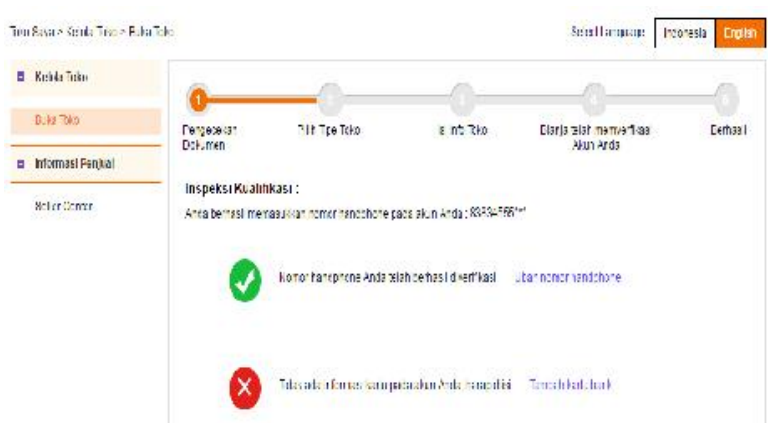

Gambar 11. Form Informasi Pemilik toko online 
Langkah berikutnya adalah mengisikan informasi mengenai toko yang akan dibuat. Yang dapat dilihat pada Gambar 12.

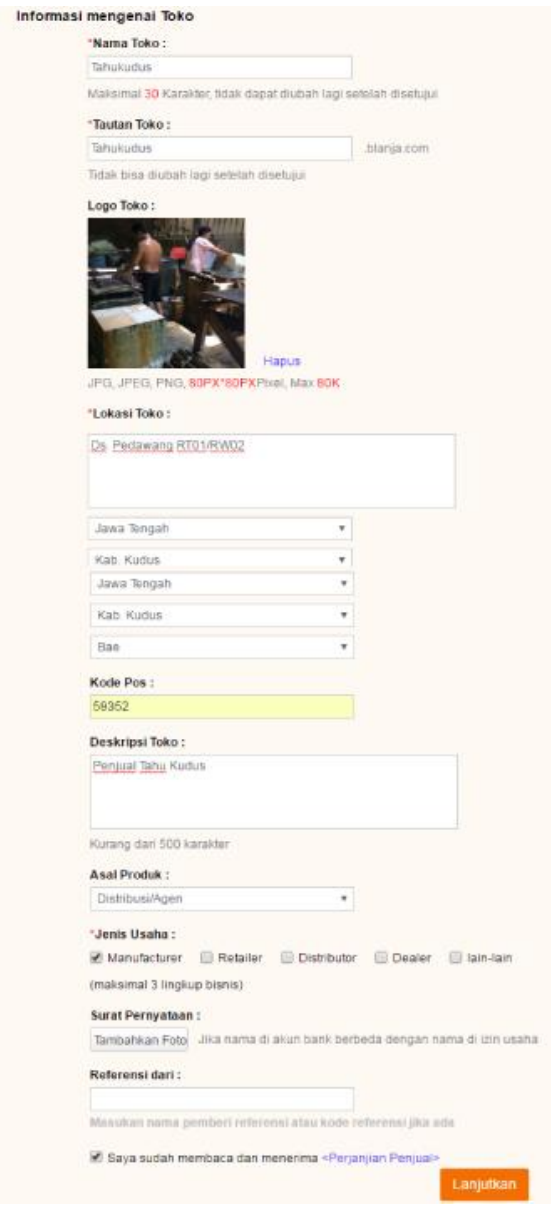

Gambar 12. Form informasi mengenai toko online

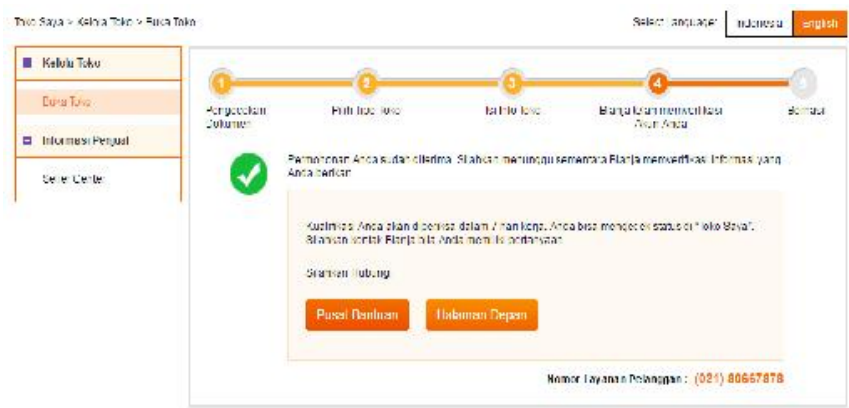

Gambar 13. Tampilan informasi toko akan segera dibuka.

\section{SIMPULAN}

Pengusaha tahu harus membuat toko online untuk meningkatkan keuntungan yang selama ini metode penjualannya dengan cara konvensional yaitu dengan cara menjual tahu di pasar tradisonal dan bertemu dengan calon pembeli lalu melakukan transaksi. Dengan memiliki toko online ini pengusaha tahu dapat memasarkan barang produksinya ke masyarakat luas dengan akses internet. Selain itu juga dapat menambah income pengusaha, serta lebih bagi pembeli tanpa harus datang langsung ke pasar tradisonal.

\section{DAFTAR PUSTAKA}

Adi N., 2011, Perancangan dan Impementasi. Yogyakarta: Andi Offset.

Ahmad N. S., Musa R., Harun M.H.M., 2015, The Impact of Social Media Content Marketing (SMCM) towards Brand Health. Fifth international conference on marketing and retailing ( $5^{\text {th }}$ incomar)

Alalwana, A.A., Ranab, N.P., Dwivedib, Yogesh K., Raed Algharabatc, 2017, Social media in marketing: A review and analysis of the existing literature: Telematics and Informatics,44, 137-140

Basso Paulo F., Pillat M. R., Oliveira T. C., 2016, Automated Design of Multi-Layered Web Information Systems. The Journal of Systems \& Software.

Kang, H., Bradley, G., 2002, Measuring the performance of IT services. International Journal of Accounting Information Systems, 3(3), 151-164.

Martin Fowler, 2005, Panduan Singkat Pemodalan Objek Standar. Jogyakarta: Andi.

Muhammad S., 2006, Membangun Aplikasi Berbasis Php Dan Mysql. Yogyakarta: Andi Offset.

Roger S Pressman, 2010, Rekayasa Perngkat Lunak Pendekatan Praktisi. Yogyakarta: Andi Offset.

Rahgu. Gehrke Johannes Ramakhisnan, 2007, Sistem Management Database. Yogyakarta: Andi Offset.

Tsai, P.S., Tsai C. C., Hwang H. G., 2011, College students' conceptions of contextaware ubiquitous learning: phenomenographic analysis, Internet and Higher Education, 14, 137-141.

Wijayanti, E. 2018. Model Social Media Content Marketing untuk Pengrajin di Kota Kudus, Jupiter UNSRI, 33-43, Politeknik 
Negeri Sriwijaya.

Yates C., 2015, Exploring variation in the ways of experiencing health information literacy: A phenomenographic study, Library \& Information Science Research, 37, 220-227. 